\title{
TOWARDS THE GLOBAL OBJECTIVE OF A COMMON PEACE FOR HUMANITY
}

\section{IMAGING OR VISUALISING PEACE}

Our second axiom, which is the focus of this chapter, is that we need to 'image' or visualise peace as the rightful possession of the human community as a whole. St Augustine speaks for all civilisations when he argues that 'there is no man who does not wish for peace' (City of God, XIX.12). 'Even when men wish a present state of peace to be disturbed', he continues, 'they do so not because they hate peace, but because they desire the present peace to be exchanged for one that suits their wishes.'

By its nature, the desire for peace becomes a desire for universal peace. Half a century ago, in 1974, Alexander Solzhenitsyn explored this dynamic in his Nobel speech: ${ }^{1}$

World literature has it in its power to convey condensed experience from one land to another so that we might cease to be divided and blinded, so that the different scales of values might be made to agree, and so that one nation might learn correctly and concisely the true history of another with as much strength of recognition and painful awareness as if it had itself experienced that history; in this way, it might be spared from repeating the same cruel mistakes. And perhaps under 
such conditions we artists will be able to cultivate within ourselves a field of vision to embrace the WHOLE WORLD: observing like any other human being that which lies nearby, and beginning to draw in what is happening in the rest of the world. And we shall correlate, and we shall have a global perspective.

The great cultural traditions of humanity, each in its own way, participate in Solzhenitsyn's hope. When we observe what is nearby, we 'begin to draw in' what is happening in the rest of the world.

Solzhenitsyn's insight is as old as the Bible:

I have given him [my servant] my spirit so that he can open up true discernment to all peoples ... Look, I have chosen you ... to be the light of nations, for a salvation that reaches to the ends of the earth.

(Isaiah 42:1-2 and 49:6)

Alexander the Great's campaign of conquest led to the emergence of new forms of connectivity across a vast region of the world. Greek philosophical schools began to question the status of the citizen-state as the primary expression of human community (Lane, 2014). The Stoic philosopher Zeno developed the ideal of the kosmopolitês or global citizen. Among the Stoics, local forms of citizenship were still taken seriously. However, as citizens of the kosmos, we have an additional perspective which must always be taken into account when we make political decisions.

Religious and philosophical traditions come together when Philo of Alexandria (1902) draws on Zeno for his portrait of Moses:

$\mathrm{He}$ is a kosmopolitēs, for which reason he is not listed on the citizen-list of any city ... he has received no parcel of land but the whole world as his portion.

(Vita Mosis: Life of Moses, 1.157) ${ }^{2}$

Today, 'the universal dimension of our civic responsibility' (Camdessus, 2019a) is demonstrable in fact. Climate risks, pandemics, the need for stable currencies, migration, development finance, the role of AI, the threat posed by new forms of violence, and many other challenges require global strategies.

In this chapter, we will explore the traditions of ancient Greece, Israel, China, and India for glimpses of how religious and philosophical thinkers visualised, or imaged, a state of general peace as the proper goal of politics. Multilateral diplomacy, as described in 
Chapter 2, has its roots in ancient ideals. We aim to demonstrate that the concept of a 'common peace', if we examine it closely, has particular attributes that deserve our close attention.

\section{THE AXIAL AGE}

In the so-called Axial Age, beginning around the 8th century BC, humanity was learning for the first time to verify by experience and articulate its political values. In many different civilisations, there emerged a social, political, and juridical space in which old ways of doing things could be examined critically and new conventions could be established.Very often, the 'felt absence' (German: Abwesenheit ${ }^{3}$ ) of justice was the factor that led to the critique of existing orthodoxies. The principle of verification produced a step change in terms of political transparency and accountability. In addition, it contributed to forms of experimental science, new technologies such as ship building, the opening of markets, and the use of coinage. Kindred developments in different spheres, taken together, represented a civilisational shift or transition.

In Confucian thought, the term 'grand union' describes an imagined society, in which 'a public and common spirit ruled all under the sky'. According to Confucius and his successors, we should work to ensure that our existing society, the 'small tranquillity', approximates, progressively, to the imagined ideal. In this perspective, leadership is a form of service to the community (Chan, 2014, p. 10).

In the prophetic and wisdom traditions of Israel, God does not create chaos or intend life in society to be unliveable. Public service is an important value. In the time of Solomon, responsibility is exercised top-down by educated court officials. In later periods, the critique of power from below acquires great importance. The anger of the prophet Amos at the workings of impersonal economic forces can be felt across the centuries:

Listen to this, you who trample on the poor and gain power over the helpless ... who say, 'we can overcharge, use false measures' ... or 'we will get a slave through having in our power a poor man who can't find even the price of a pair of sandals to pay us off'.

(Amos 8:4-6) 
In India, the Buddha breaks with an inherited conglomerate of political, economic, and religious power, crystallising a tradition of dissent (the Sramana or Samana tradition) that has deep origins in Indian society (Gandhi, 1999, p. 39). In the 3rd century BC, in a development of the Buddhist tradition, the Emperor Ashoka promotes peace through dharma, the inner law that shapes all being, and is, at the same time, a humane code of conduct embracing all aspects of life (Thapar, 1961). Ashoka commissions a series of inscriptions, the so-called Rock Edicts and Pillar Edicts, to make known the elements of dharma throughout his domains. One of the most famous of these inscriptions, the 4th Rock Edict, proclaims that 'the sound of the drum has become the sound of dharma'. Formerly, drums were used for leading forces into battle; now, according to the king, the population will be organised for peaceful purposes.

In 5th-century Athens, Socrates and other thinkers responded to the breakdown of human communities by asking a series of structural questions about politics and human nature. The Greeks perceived an analogy between politics and the emerging science of medicine: the better we understand how political and social systems work, the more we can become agents of change. 'Therapy of the common interest' (therapeuein ta koina) is a political term of art (Thucydides, 1996, III.82:8). Lawgiving and justice are described by Socrates (Plato, Gorgias, $464 \mathrm{~B}-\mathrm{C}$ ) as 'political therapy' (therapeia tēs politikēs).

The examples that we have used from the Axial Age Confucianism, the prophetic traditions of Israel, Buddhism, and Greek political science - suggest that suffering and division do not have the decisive word in human history. Civilisational values can change for the better over time. That change can be sustained through centuries.

In the Axial Age, a religion or worldview is interwoven in the process of change. Often, a religious tradition emerges from an epoch of change with a clearer self-understanding. Is the 'state of nature' a war of all against all? Or are we disposed 'by nature' to a creative, cooperative way of life in harmony with the 'natural world'? The pathfinding thinkers of the first millennium BCE offer hopeful answers to such questions.

Many aspects of the Axial Age are open to debate. The degree to which developments at different times and places are interconnected 
is disputed, as is the degree to which other societies, less well studied, have developed similar ideas to ancient Greece, or India, or China. In any case, civilisations can no longer be seen as walled off from one another and self-sufficient:

Knowledge systems that have governed world history have no single source. Thus, the direction taken by mathematics, astronomy, and medicine evolved from an intersection of ideas that were Chinese, Indian, Greek, and Arab, and these were developed further in Europe.

(Thapar, 2008)

For some of the leading exponents of the Axial Age, it was important to visualise the various earlier civilisations as tributaries flowing into an 'achieved' Western civilisation, as they saw it at the time. The question of 'impact' arises in a different way when we compare the Axial Age to other major patterns in history. The conquests of Alexander the Great began a process of globalisation in the Mediterranean, the Middle East, and Asia as far as the Oxus. The Roman Empire, borrowing from Alexander, developed a formidable political narrative of its own. For the purposes of this book, it is not necessary to settle the arguments around parallels, connections, continuity, and relative impact. The Axial Age is the template, not the taproot, for the prise de conscience at the global level for which we advocate in this book.

What happened in the Axial Age, viewed as a template, can be compared to what has begun to happen in modern Western society since women acquired the right to vote. Ultimately, the change is not a matter of one or two specific reforms - that women vote or achieve top positions within powerful institutions. Nor does the emancipation of women, in itself, enable the development of new forms of governance at the global level. What the emancipation of women implies in the longer run is a changing disposition - an end to patriarchy, new role models for young people, more enlightened social priorities, and a better understanding of what power really is. This can fairly be described as a process having anthropological significance.

\section{EIGHT KEY CONCEPTIONS REGARDING THE NATURE OF PEACE}

The great civilisations of the Axial Age share a number of key conceptions regarding the nature of peace. By way of provoking a 
discussion, we will develop eight mutually supportive ideas, inspired by both ancient and modern experience.

\section{PEACE IS THE NORM}

First comes the hope that destructive division will not have the last word in human history. Peace is the norm. A state of general or common peace is the proper goal of politics. In their search for a conception of equilibrium in society, Greek writers use analogies based on musical composition, the harmony between organs of the body, and mathematical equations. Today, the Institute for Economics and Peace (IEP) in Sydney has developed a metric for assessing the attitudes, institutions, and structures that sustain peaceful societies. This is sometimes referred to as a systems approach: a well-functioning government, the rule of law, low levels of corruption, and a strong business environment interact with factors such as access to information, respect for others, and the effective distribution of wealth to make for a flourishing system or 'ecology'. To achieve 'positive peace', we need to look for improvements in relation to all the main indicators or pillars on which peace depends.

\section{FREEDOM IS CORRELATIVE WITH LEGITIMATE AUTHORITY OR LEADERSHIP}

In addressing point two, a good place from which to start is that, in Confucian thought, channels of communication and consultation enable political leaders to demonstrate that they are at the service of the people, and the people themselves to develop trust in their political leaders: the 'perfecting' of relationships is centrally important (Chan, 2014).

In the Prometheus Bound of Aeschylus, Zeus, who dominates, and Prometheus, in chains, are essentially equal - both are Titans. What is missing in their interaction is freedom: Prometheus has been nailed to a rock by agents of Zeus whose names are Power and Force. At stake in the drama is whether a relationship based on freedom mutual willing consent (hekōn hekonti) - can be restored at some point in the deep future.

In Thucydides, war is a 'savage teacher' (biaios didaskalos), lowering people's horizons to the problem of mere survival (Thucydides, 1996, III.82:2). At its best, on the other hand, political life is an 
education (paideia) that introduces us to life in community. The theme of the Funeral Oration of Pericles, history's most influential statement of the democratic ideal, is that to engage with others in creating a common life can become an expression of love. There is a read-across to 'Confucian perfectionism'.

The connotations of Hebrew terms such as shalom ('peace and human flourishing'), hesed, (loving kindness and equity'), and tsedakah ('justice-with-mercy') point towards a vision of peace as bringing out the personal maturity that we discussed in Chapter 1.

In St Augustine, we turn to social organisation because we are similar to one another in what we love (like Zeno's 'cosmopolitans'):

If one should say, 'A people is the association of a multitude of rational beings united by a common agreement on the objects of their love,' then it follows that to observe the character of a particular people we must examine the objects of its love.

(City of God, XIX.24)

In the Axial Age, freedom often came to be understood as the condition of authentic human relationships based on good will. Freedom and force are discordant; freedom and legitimate leadership are correlative.

\section{TRUTH IN ALL ITS FORMS IS THE CONCERN OF POLITICS}

To reflect on our third point, before his death the Buddha addresses his disciples as follows:

'You must be your own lamps, your own refuges ... Hold firm to the truth as a lamp and a refuge' (conversation with Ananda in the Digha Nikaya, quoted by Gandhi, 1999, p. 37).

Siddhartha Gautama - the Buddha - engages with individuals at all levels of society to enable them to see that the brutal power politics of the Magadha kingdom and the ramifications of the caste system do not express any ultimate truth about human nature.

For the prophet Zechariah, the ability to 'see' to form a right judgement about a shared situation is the gift of a 'spirit of kindness and mercy $\ldots$ a pure Spirit' $(12: 10,13: 2)$. Below are some lines from the second chapter of Zephaniah (verse 3):

Seek the Lord, all you, the humble of the earth ... 


\section{Practise discernment seek justice.}

In the Second Letter to the Thessalonians (2:7), St Paul speaks of the mystery of iniquity at work in the world. Iniquity (in Latin, iniquitas; in Greek, anomia) suggests not so much the absence of law as the presence of a distorted law - a law confused and corrupted by a dangerous admixture of untruth. One is reminded of Shelley's (2003, p. 401) 'Mask of Anarchy':

Last came Anarchy: he rode

On a white horse, splashed with blood;

He was pale even to the lips, Like Death in the Apocalypse.

And he wore a kingly crown;

And in his grasp a sceptre shone;

On his brow, this mark I saw -

'I AM GOD, AND KING, AND LAW!

In many biblical texts, the just man (Greek: dikaios) is the standard, in fact the only standard, by which iniquity, or false law, or not-law can be revealed for what it is. In both the Septuagint and the New Testament, the just person's capacity for true judgement is rendered by the word krima or krisis (including in Isaiah and Zephaniah, as quoted above).

Even in ancient societies firmly based on top-down rule, such as the Persian Empire, the freedom to speak the truth or even to act independently in the light of the truth represents the cultural ideal. In Xenophon's 4th century BCE biography of Persia's King Cyrus, the king has two good counsellors - Hystaspes and Chrysantas (Cyropaedia, Book IV).The first obeys the king willingly. The second, even more to be admired, carries out, without instructions, "what he himself sees it was better for us to have done'. Friendship and truth are linked values within this idealised picture of the administration of Cyrus.

\section{THE NEED TO NURTURE OUR PRE-POLITICAL CULTURE}

Fourth, our capacity for loyal opposition, our ability to stand back and criticise in the common interest, depends on the quality of our 'pre-political culture' - of a social reality antecedent to political engagement. Out of a private space come political and social 
engagement - the ability to intervene with others to change the social dynamic and build communities.

Aeschylus and other figures of the Athenian Golden Age speak of the innate 'reverence' (deos, aidoss) on which the practice of politics depends. For Pericles in the Funeral Oration, there is already an important 'private' side to the Athenian project: the democratic constitution underpins a whole way of life, much of which takes place in the home, at festivals, and in the theatre, away from politics.

In the Hebrew tradition, the covenant is antecedent to any political arrangement. In India, the shramana dharma (way of life) involves distancing oneself from the political and economic powers-that-be in order to have the freedom to promote social justice. In this respect, there is a line of continuity from Buddhism, through the Bhakti sants, the Sufis within Islam, and the Sikhs, all the way to Mahatma Gandhi.

\section{THE IMPORTANCE OF DIALOGUE}

Fifth, to build a 'common peace' where it does not yet exist, we need to understand the nature of dialogue. The aim of ancient Greek or Indian philosophical dialogue was to bring intellectual coherence to a potentially chaotic environment by defining the principal arguments in play and bringing these arguments into contact with one another. Greek writers pictured the common logos or 'shared account of how things are' (Heraclitus, 1957, Fragments 1, 2, and 50). To understand what is at stake, let us look at a recent statement from an American scholar of international relations (Mandelbaum, 2019, p. 144):

If Russia, China, and Iran were to adopt, by whatever route, fully democratic political systems including both popular sovereignty and the protection of economic, religious, and political liberty, the need for nationalist assertion as a source of legitimacy would shrivel.

Like many other American scholars, Mandelbaum operates with a presumption that democracies, almost by definition, are less aggressive than other states. Thucydides would smile: a lifetime comparing Athens to Sparta did not lead him to this conclusion.

Mandelbaum sees the post-Cold War period (between 1990 and 2015) as an era of peace largely attributable to the 'benign hegemony of the United States' (Mandelbaum, 2019, p. 136).The principal 
obstacle to a future world free of 'security competition' is constituted by three countries - Russia, China, and Iran - whose governments, according to Mandelbaum, are acting out of false motives. The US is in a different category because of the 'liberties' that it promotes (no distinction is made between the categories of religious, political, and economic freedom).

Mandelbaum is moderate in comparison with some American thinkers; he does not countenance undermining or overthrowing the governments that stand in the way of his ideas. Nevertheless, he embodies some of that 'existential mistrust' to which we referred in Chapter 1, in that he does not appear to accept Moscow, Beijing, or Tehran (or, by implication, many others) as valid dialogue partners.

In his speech when he received the Charlemagne Prize in 2016, Pope Francis said the following:

There is an impression that Europe is tending to become increasingly 'entrenched', rather than open to initiating new social processes capable of engaging all individuals and groups in the search for new and productive solutions to current problems.

Governments should acknowledge that every time they say of a critic or an opponent, 'if he is not a hundred percent right, he may be ten or twenty percent right', they are creating a space in which trust can develop, and international society can begin to find 'new and productive solutions to current problems'.

\section{THE VALUE OF FRIENDSHIP}

Sixth, political society is promoted to a great extent by friendship, by what we choose to do for its own sake. Aristotle examines the role of friendship in politics in great depth and detail in Books VIII and IX of the Nicomachean Ethics. Using the example of travelling companions, he argues that our pursuit of a common project tends as a matter of experience to turn into friendship (philia). The 'shared journey' of the travelling companions becomes a metaphor for community in all its forms: the family, soldiers on campaign together, men embarked on a business venture, religious festivals at the local level, and finally, the polis or citizen-state itself.

In the political community, the detailed provisions of the law become less important as friendship takes root (Nicomachean Ethics, 
VIII.1). Friendship even leads to self-sacrificing actions that contradict self-interest as ordinarily understood. In 2020, Aristotle's discussion of the role of friendship in political life is a lens through which to study the levels of 'social capital' available in different societies as we struggle with COVID-19.

\section{THE TEST OF CIVILISATION IS THE ABILITY}

\section{TO INTEGRATE NEW PEOPLE AND IDEAS}

In terms of the seventh point, Homer is famously impartial between the Greeks and Trojans. Aeschylus writes a play, with Pericles as producer, in which the very recent Persian invasion is looked at through Persian eyes. Thucydides notes that foreigners are in attendance as Pericles delivers the Funeral Oration. Sparta's expulsion of foreigners is one of the issues at stake at the outbreak of the Peloponnesian War (Thucydides, 1996, I.144.2).

Indian civilisation is a confluence of many streams - tribal or indigenous cultures; religious writings in Sanskrit and Tamil; Buddhism and the other religious traditions growing out of Hinduism; the multifaceted culture of the Mughals; the Persian influence on the languages of North India; Gandhi and the struggle for independence; the great works of creative literature in several languages, including English; European influences that include British law; and economic globalisation.

When Virgil is asked to write an epic poem to celebrate the greatness of Rome, he builds the story around a refugee driven by fate, whose task is to journey from Troy into the unknown, accompanied by a remnant of his people and preserving only his religion, the essence of the old way of life; everything else changes. Aeneas's journey ends in Latium in Italy. There he founds a new realm based on the coexistence of Trojans, Latins, Greeks, and Etruscans.

The post-war European project draws on deep cultural sources in the attempt to re-create a European civilisation based on forgiveness of the past and allegiance freely given to a future common good. The revived Europe, according to its own ideals, shares with the humanism of the early Renaissance the ability to offer hospitality to many different strands of history and culture, including, since the fall of the Berlin Wall, a large number of new member states. 
According to its own ideals, Europe is 'dynamic', aiming at an economy of solidarity at home and abroad. The most important early statement of the European ideal is the Schuman Declaration of May 1950, ${ }^{4}$ which contains the following sentence:

With increased resources, Europe will be able to pursue the achievement of one of its essential tasks, namely, the development of the African continent.

As so often happens, one day's moral imperative is the future's compelling political logic. The population of Africa may exceed the population of Europe several times over by the end of the present century. To turn the encounter of cultures and peoples across the Mediterranean into a journey that enriches us all will be a central challenge of the decades ahead.

\section{ENLARGING THE COMMON SPACE}

Eighth, and finally, the desire for peace, unless, in St Augustine's famous phrase, it is a magnum latrocinium (a 'vast conspiracy among thieves'), broadens into the desire for a common peace.

Ashoka's 13th Rock Edict expresses the idea of 'conquest by dharma', instead of by war or violence (Thapar, 1961, pp. 256-257). The adoption of the principles of dharma by neighbouring states creates a common moral space.

Zeno and the Stoics, as mentioned above, taught that for the wise there exists in principle a global order, a kosmos. One of Plutarch's moral essays describes Alexander the Great as a philosopher in action whose policy was to reconcile peoples and civilisations. In this connection, Plutarch summarises the Stoic vision of a global society (Moralia, 329 a-c):

all the inhabitants of this world should not live differentiated by their respective rules of justice into separate cities and communities ... we should consider all men to be of one community and one polity, and we should have a common life and an order common to us all, even as a herd that feeds together and shares the pasturage of a common field.

A national political community is an energy system that inevitably comes into contact with other energy systems: unless this contact is mediated by customs, agreements, and formats for dialogue, it is easy 
to predispose ourselves to aggression through an inward-looking, truth-distorting, historical narrative marked by 'existential mistrust'.

\section{INDEPENDENT SHARED VALUES}

Our eight characteristics of peace, discussed above, can be understood as facets of an evolving process, namely, creating and sustaining independent, shared values, and a vocabulary to support them, through acts of solidarity and frameworks for dialogue, as well as legally binding decisions. Such values are shared, because moral norms are above any individual; and they are independent, because moral norms are more than social conventions. Our 'characteristics of peace' demonstrate that the 'granular' provisions of established law are an inadequate foundation for society, for several inescapable reasons.

The law is incomplete. To take what we can within the limits of the law is not necessarily right. For ancient writers, limits on the pursuit of gain are defined by 'unwritten law'.

The lawgiver will not have reckoned with the precise circumstances of every case. Any law should therefore be applied in a 'personal' way, with discernment and an element of mercy.

Background circumstances change. In times of political upheaval, a citizen's obligations under the law can become unclear. Do we serve a revolutionary government? How do we define our obligations under rapidly changing international circumstances?

That citizens have regard for one another, or that nations trust one another, is an outcome of politics, not a 'constitutive choice' within the political process. 'Fraternity' is elusive - harder to achieve than 'liberty' or 'equality'. In the light of the constant interaction between independent, shared values and the granular provisions of the law, we can state that political values fall into three baskets:

1. 'Pre-political values' are the ideas and approaches - the orientation, the methodology, the world view, and the axioms of the historical imagination - with which we approach politics.

2. By political values, we mean laws, treaties, and concrete policies. Political values are often 'granular'.

3. In the realm of 'post-political values', we can place, for example, the strengthening of friendship and solidarity that can arise as a result of the right political decisions. 
The instinct of ancient civilisations is that society is held together, ultimately, by a sense of the sacred; hence, the emphasis placed by ancient cultures on dharma, custom, decorum, rites and rituals, the sacredness of oaths, and the inviolability of sanctuaries. Serious politics means giving due weight to the realm of religion and human values.

\section{'IF YOU WANT PEACE, WORK FOR JUSTICE'}

In his message for the World Day of Peace in 1972, Pope Paul VI called for 'a new expression of Justice, a new foundation for Peace'. The central idea is that persons in 'posts of responsibility' should avoid the temptation to impose rules by force. In any given group - a family, a school, a workplace, a community, a city, a state - 'normal relations' should be established in a manner that respects the dignity and freedom of each person. Drawing on the saying of the prophet Isaiah that the fruit of justice is peace (32:17), Pope Paul formulated the maxim, 'If you want peace, work for justice'. In this choice of words, there is an implied allusion to a very different Roman maxim cited by a military writer of the 4th century CE: 'if you want peace, prepare for war'. ${ }^{5}$

Working for justice, achieving the global objective of a common peace for humanity, removing mere force from our political equations, and delivering democracy are ultimately one and the same struggle, if we accept the following definition of democracy, offered by Pope Benedict XVI (2006): ${ }^{6}$

Democracy will be fully implemented only when all individuals and all peoples have access to life, food, water, healthcare, education, work, and certainty of their rights, through an ordering of internal and external relations that guarantees everyone a chance to participate.

\section{A MEDIUM-TERM PERSPECTIVE}

On what time scale should we pursue an 'age of sharing', an Axial Age at the planetary level?

The Israeli historian Yuval Noah Harari has written three best-selling books on the past and future of our species. Harari's narrative begins with the appearance of matter and energy 13.5 billion years ago and passes via the origins of organic life 3.8 billion years ago to the start of human history perhaps about 70,000 years 
ago with the development of language. In this long perspective, Harari sees the present century as a turning point. Through biological engineering and other interventions, we may soon be able to bring about physiological changes and changes in consciousness that will call human identity into question. For Harari, this breaking free of biologically determined limits is even more significant than the destruction of the environment and the proliferation of nuclear weapons. Below is a summation of one of Harari's (2014, pp. 415-416) key conclusions:

We are more powerful than ever before, but have very little idea what to do with all that power ... Self-made gods with only the laws of physics to keep us company, we are accountable to no one ... Is there anything more dangerous than dissatisfied and irresponsible gods who don't know what they want?

The premise of this book is that we have reached a 'point of inflection' in international affairs and that the moral and political vacuum pinpointed by Harari represents a clear and present danger. The challenge is to prevent impersonal forces from shaping events and compromising our planetary future.

That said, do we expect in the 21st century, or in any foreseeable future, to bring about a lasting, all-encompassing political system of the kind dreamt of in ancient Rome? Or should we focus, not on a new Pax Romana, but in the medium-term - on what can be achieved within the next generation - by seeking to harmonise religious, cultural, political, and economic factors as best we can in order to extend, where needed, a shared form of historical literacy and a capacity for common action?

Many religious voices have encouraged the idea that the United Nations is a providential initiative, a 'necessary path' presenting itself just as humanity has come to a historical crossroads. Addressing the UN General Assembly during the hope-filled post-war era, Pope Paul VI (1965) said: 'a wish borne in our heart for almost twenty centuries is being accomplished ... we are celebrating ... an opportunity to speak heart to heart with the whole world. ${ }^{7}$

The Pope's vision of dialogue in support of a global culture of peace is rooted in a century of growing activism by religious leaders. Significant milestones include the World Parliament of Religions in 
Chicago in 1893 and the peace plan of Pope Benedict XV in midWorld War I.

Arguably, this awakening of religious interest in questions of world organisation is attributable in part to the changing face of war in the 19th century. Powerful states were building standing armies, sometimes through conscription, and equipping them by means of an ever-growing military-industrial establishment. One of the main proposals laid before the First Vatican Council, convened in 1869 , was to lend the authority of the Church to a strengthened Law of Nations, with particular reference to disarmament, arbitration, the redirecting of resources to the poor, and education for peace. Before this agenda for peace could be developed, the Franco-Prussian War led to the abrupt end of the Council (Araujo and Lucal, 2004, pp. 52-55). An analogous agenda for peace is central to the development of the Baha'i faith during the same period. In 1867 and 1868, Bahá'u'lláh addressed 'tablets' to kings and rulers urging them to establish a system of collective security, move towards disarmament, and show care and consideration for the rights of the poor.

In the 21st century, religious actors have continued to demonstrate a positive attitude towards the UN and the principle of global cooperation. This is reflected, for example, in faith-based initiatives in support of the UN SDGs (as mentioned in the Introduction) and human rights (Beirut Declaration, 2017).

But the question is, does the path of planetary awareness lead to a definite destination in terms of the future political organisation of the planet?

The Roman Empire with its Pax Romana offered a political vision that pointed in some respects towards the unity of peoples. But this unity was in practice extremely uneven in its effects and relied partly on severe coercion; for some perceptive writers of the time, unity based on Roman power and Roman state religion repeated many of the same damaging patterns of thought that characterised earlier national societies, only this time in the name of a much larger political entity.

Furthermore, it contradicts all the evidence of history to suppose that some revolution in our affairs will obviate the need for politics or exempt future generations from difficult acts of discernment. 
Therefore, the right approach, we argue, is to work towards insights or axioms that are liberating in our present cultural context. We should think mainly in a medium-term perspective, laying down a path or throwing a bridge to the future. The goal is to prepare rather than pre-empt the choices to be made by the next generation.

There may be a useful distinction to be made between, on the one hand, the principle of a 'world political authority', and on the other hand, the practical objective of working towards a global 'civilisation' or 'common peace'. The difference between a 'world authority' and a 'common peace' resides partly in the difference between building an overarching political structure and nurturing the pre-political values out of which rules, programmes, budgets, and initiatives can be developed step by step.

We should aspire to moving gradually, by non-violent methods, from unexamined patterns of control and confrontation to conscious cooperation, from force-based structures to truth-based structures. Once this journey towards justice is underway, good will and friendship will take root. As a medium-term objective, we should work at the global level to transform habits and assumptions and create common reference points; but not - or not now - as a means to a single form of government on a planetary scale.

Global systemic change is already much discussed in relation to climate change. In that context, 2050 is mentioned as the date by which humanity needs to find a new direction. Our particular premise, that axioms of the historical imagination are an essential part of long-term diplomatic strategy, should be explored in the perspective of that time scale. To arrive at a better common understanding of the nature of effective action, and the role of religion in helping to enable effective action, will require multifaceted efforts over decades.

\section{NOTES}

I Solzhenitsyn's speech can be found on the website of the Nobel Foundation at www.nobelprize.org.

2 This passage was drawn to our attention by Oswyn Murray.

3 We are grateful to Dirk Evers for an illuminating discussion of the connotations of this German word.

4 The Schuman Declaration is available on the website of the Robert Schuman Foundation at: www.robert-schuman.eu/en/declaration-of-9-may-I950. 
5 Vegetius' De Re Militari.

6 In his 2006 speech to members of the Centesimus Annus Pro Pontifice Foundation, Clementine Hall, Friday I9 May; www.vatican.va.

7 In his address on 4 October I965; https://w2.vatican.va/content/paul-vi/ en/speeches/I965.index.html.

\section{REFERENCES}

Araujo, R.J. and Lucal, J.A. (2004). Papal Diplomacy and the Quest for Peace: The Vatican and International Organisation from the Early Years to the League of Nations. Ann Arbor, MI: Sapienta Press.

Aristotle. (I972 [1925]). Nicomachean Ethics, translated with an introduction by Sir David Ross. London: Oxford University Press.

Augustine. (1972). City of God, translated by H. Bettenson with an introduction by David Knowles. Harmondsworth: Penguin Books.

Benedict XVI. (2006). Speech to the Participants in the Meeting Sponsored by the Centesimus Annus Pro Pontifice Foundation, I9 May. www.vatican.va.

Camdessus, M. (20I9). 'Faith in a Better World: Embracing the Mission to Shape the World of Tomorrow.' Address to the 7th Faith and Life Convention, Belfast, 27 September.

Chan, J. (20I4). Confucian Perfectionism: A Political Philosophy for Modern Times. Princeton and Oxford: Princeton University Press.

Francis. (2016). Conferral of the Charlemagne Prize: Address of His Holiness Pope Francis, 6 May, Vatican. www.vatican.va.

Gandhi, R. (1999). Revenge and Reconciliation: Understanding South Asian History. New Delhi: Penguin Books India.

Harari,J.N. (20I4). Sapiens: A Brief History of Humankind. London: Harvill Secker. Heraclitus. (I957). In the Diels-Kranz ordering, in G.S. Kirk and J.E. Raven. The Presocratic Philosophers. Cambridge: Cambridge University Press.

Kirk, G.S. and Raven, J.E. (I957). The Presocratic Philosophers. Cambridge: Cambridge University Press.

Lane, M. (20I4). Greek and Roman Political Ideas. London: Pelican.

Mandelbaum, M. (2019). The Rise and Fall of Peace on Earth. Oxford: Oxford University Press.

Office of the United Nations High Commissioner for Human Rights (OHCHR). (20I7). 'The Beirut Declaration and Its I8 Commitments on "Faith for Rights".' www.ohchr.org.

Paul VI. (I965). 'Address to the United Nations Organisation,' 4 October. https://w2.vatican.va/content/paul-vi/en/speeches/I965.index.html.

Paul VI. (I972). 'Message for the World Day of Peace.' https://w2.vatican.va/ content/paul-vi/en. 
Philo of Alexandria. (I902). 'De Vita Mosis, Lib. I,' in L. Cohn (ed.), Philonis Alexandrini Opera Quae Supersunt,Vol. IV. Berlin: Reimer.

Plato. (1925). Lysis, Symposium, Gorgias, translated by W.R.M. Lamb. Loeb Classical Library. Cambridge: Harvard University Press.

Plutarch. (1936). Moralia, Vol. IV, including the essay 'On the Fortune or Virtue of Alexander,' translated by F.C. Babbitt. Loeb Classical Library. Cambridge: Harvard University Press.

Shelley, P. (2003). 'The Mask of Anarchy', in Z. Leader and M. O'Neill (eds.), Percy Bysshe Shelley: The Major Works. Oxford: Oxford University Press.

Thapar, R. (I96I). Aśhoka and the Decline of the Mauryas. Oxford: Oxford University Press.

Thapar, R. (2008). Humanities in a Globalising World. Speech on the Presentation of the 2008 Kluge Prize, Library of Congress.

Thucydides. (1996). The Landmark Thucydides: A Comprehensive Guide to the Peloponnesian War (revised edition of the R. Crawley translation), edited by R.B. Strassler. New York: Free Press.

Xenophon. (1998) Cyropaedia: Bks. 1-4, translated by W. Miller. Loeb Classical Library. Cambridge: Harvard University Press. 